U. S. COMMISSION OF FISH AND FISHERIES.

GEORGE M. BOWERS, Commissioner.

\title{
ARTIFICIAL PROPAGATION
}

OF THE

\section{BLACK BASSES, CRAPPIES,}

\section{ROCK BASS.}

Extracted from the Revised Edition of the Fish Manual. Pages 147 to 163, Plates 47 to 60.

WASHINGTON:

GOVERNMENT PRINTING OFEICE.

1900. el? 
ช 

U. S. COMMISSION OF FISH AND FISHERIES.

GEORGE M. BOWERS, Commissioner.

\section{ARTIFICIAL PROPAGATION}

OF THE

\section{BLACK BASSES, CRAPPIES,}

AND

\section{ROCK BASS.}

Extracted from the Rerised Edition of the Fish Manual. Pages 147 to 163, Plates 47 to 60.

\section{WASHINGTON:}

GOVERNMENT PRINTING OFFICE. 



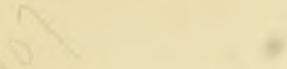

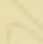

$x=$

공

rix

D. 


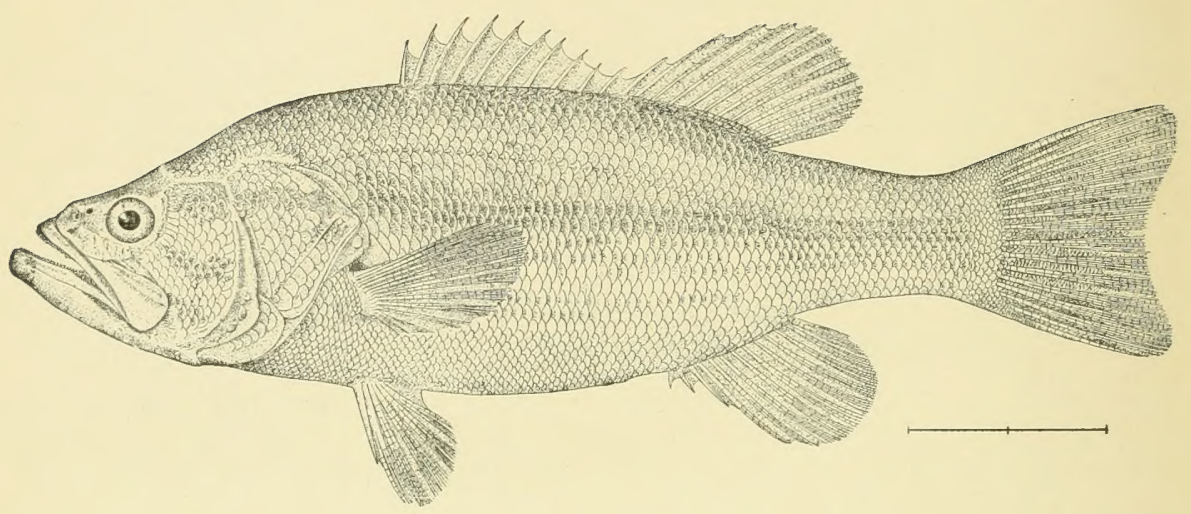

MICROPTERUS SALMOIDES. Iarge-mouthed Black Bass.

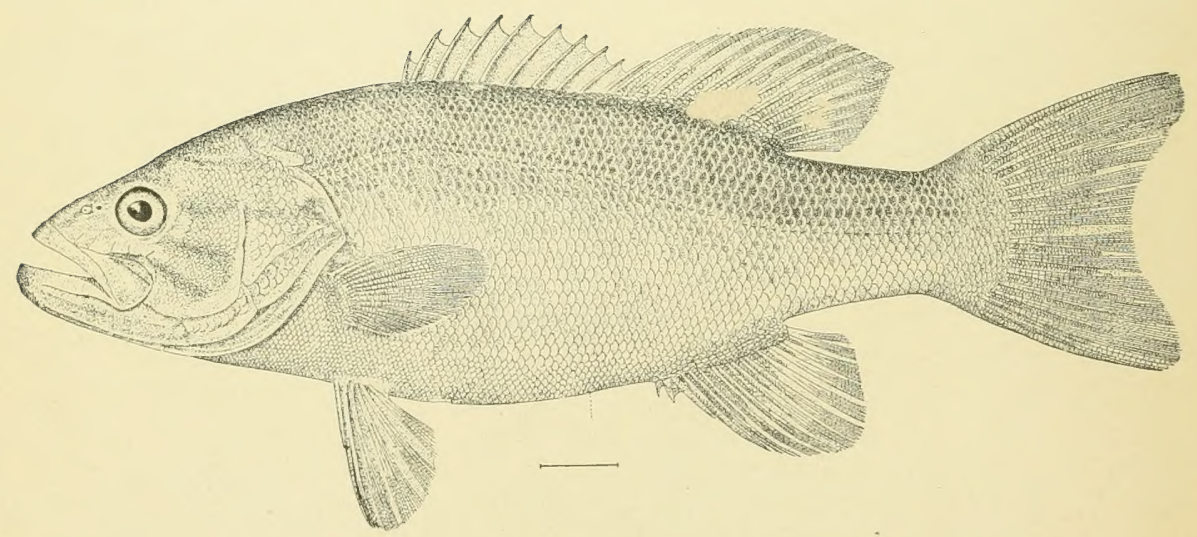

MICROPTERUS DOLOMIEU. Small-mouthed Blark Buss. 


\section{THE BLACK BASSES, CRAPPIES, AND ROCK BASS.}

\section{DESCRIPTION OF THE FISHES, COMMON NAMES, E'TC.}

The species treated of in this chapter are those members of the Centrarchidae (or fresh-water sunfishes) which have come under the scope of tish-culture, namely, the large-mouth black bass (Micropterus salmoides), the small-mouth black bass (Micropterus dolomieu), the rock bass (Ambloplites rupestris), the crappie (Pomoxis annularis), and the calico bass (Pomoxis sparoides). Whatever is said of the rock bass will apply equally well to other sunfishes, which might be here considered but which have not been artificially reared.

The principal physical characters of these fishes are indicated in the following key, which serves to distinguish the two species of black bass and the two species of crappie from each other as well as from less closely related species.

Large-mouth black bass: Body comparatively long, the depth about one-third the length; back little elevated; head large, 3 to $3 \frac{1}{2}$ in body; eye 5 to 6 in head; mouth very large, the maxillary in adults extending beyond eye, smaller in young. Ten rows of scales on the cheeks; body scales large, about 68 in the lateral line, and 7 above and 16 below the line. Dorsal fin low, deeply notched, larger than anal, with 10 spines and 12 or 13 soft rays; anal with 3 spines and 10 or 11 rays. Color above dark green, sides greenish-silvers, belly white; young with a blackish band along sides from opercle to tail, the band breaking up and growing paler with age; caudal fin pale at base, white on edge and black between; older specimens almost uniformly dull greenish; three dark oblique stripes across opercle and cheek; dark blotch on opercle.

Small-mouth black bass: Similar in form to large-mouth bass. Mouth smaller, the maxillary terminating in front of posterior edge of eye, except in very old specimens. About 17 rows of small scales on the cheeks; body scales small, 11-74-17. Dorsal fin less deeply notched than in other species, with 10 spines and 13 to 15 rays; anal with 3 spines and 12 or 13 rays. General color dull golden-green, belly white; young with dark spots along cides tending to form irregular vertical bars, but never a lateral banc: caudal fin yellowish at base, white at tip, with dark intervening area; dorsal with bronze spots and dusky edge; three radiating bronze stripes extending backward from eye; dusky spot on point of operele.

Crappie: Body short, greatly compressed, back much elevated; depth 
$2 \frac{t}{3}$ in length; eye large, one-fourth length of head; head long, 3 in length; profile with double curve; mouth large, snout projecting. Scales on cheeks in 4 or 5 rows; scales in lateral line 36 to 48 . Dorsal fin smaller than anal, with 6 spines and 15 rays, the spinous part the shorter; anal with 6 spines and 18 rays; dorsal and anal fins very high. Color silvery white or olive, with mottlings of dark green; the markings mostly on upper part of body and tending to form narrow, irregular vertical bars; dorsal and caudal fins with dark markings; anal nearly plain. The figure of this species on the opposite page is scarcely typical in the pattern of markings.

Calico bass: Similar in form to crappie, but the body shorter, back more elevated, and profile of head straighter; depth, one-half length; head one-third length; mouth smaller than in crappie; snout less pro jecting. Six rows of scales on cheeks, and 40 to 45 along lateral line. Dorsal and anal fins higher than in crappie; dorsal spines 7 or 8 , rays 15 ; anal spines 6 , rays 17 or 18 . Color light silvery-green, with dark-green irregular mottlings over entire body; dorsal, caudal, and anal fins with dark-olive reticulations surrounding pale areas; whole body sometimes with a delicate pink reflection (whence the name strawberry bass).

Rock bass: Body oblong, compressed, back moderately elevated; depth 2 to $2 \frac{1}{2}$ in length; head large, $2 \frac{3}{4}$ in length; eye very large, $3 \frac{1}{2}$ in head. Scales $5-39-12$, in 6 to 8 rows on eheeks. Dorsal fin much larger than anal, with 11 spines and 10 rays; anal, with 6 spines and 10 rays. Opercle ending in two flat points; gillrakers less than 10. Color olive-green, with brassy reflections; young irregularly barred and blotched with black; adult with a dark spot at base of each scale, forming interrupted and inconspicuous stripes; a black spot on opercle; anal, caudal, and soft dorsal fins with dark mottlings.

The most reliable character for distinguishing the large-mouth from the small-mouth bass is the number of rows of scales on the cheeks. The colors of each species vary with age and the size of the mouth varies with the size of the fish, but the scales are constant under all conditions. With the crappies, the leading differential feature is the number of dorsal spines.

By reason of their wide geographical range, the black basses have received a multiplicity of popular names. The large-mouth black bass is known as Oswego bass, lake bass, green bass, yellow bass, moss bass, bayou bass, trout, jumper, ehub, and welshman. In the North it is generally called black bass; in Virginia and North Carolina it is usually designated as the chub, and in Florida and the Southern States it is often called trout. The small-mouth black bass has received the common names of lake bass, brown bass, ninny bass, hog bass, black perch (used in the mountain sections of Virginia, Tennessee, and North Carolina) trout perch, brown trout, jumper, mountain trout, together with other names of purely local use.

Rock bass are variously known as red-eye, red-eye perch, and goggleeye, and are sometimes confounded with the warmouth (Chonobryttus gulosus), which bears some of the same common names. 
The ealico bass has also received the names of strawberry bass, griass; bass. bitter-head. barfish, lamplighter, goggle-eye, goggle-eye pereh, speckled perelh, and speckled tront. The crappie is known in its native waters as ('apple, new light, 'ampbellite, sac-a-lait, bachelor, chinquapin perch, (roppie, and rropet. On account of the similarity of the

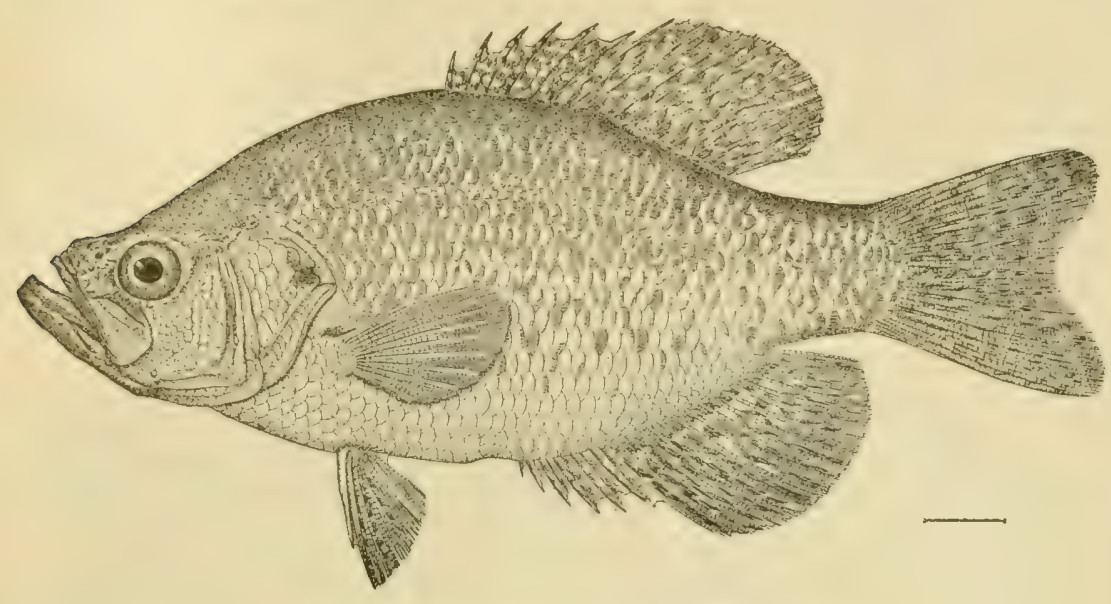

Ponoxis annumiris. 'rappie.

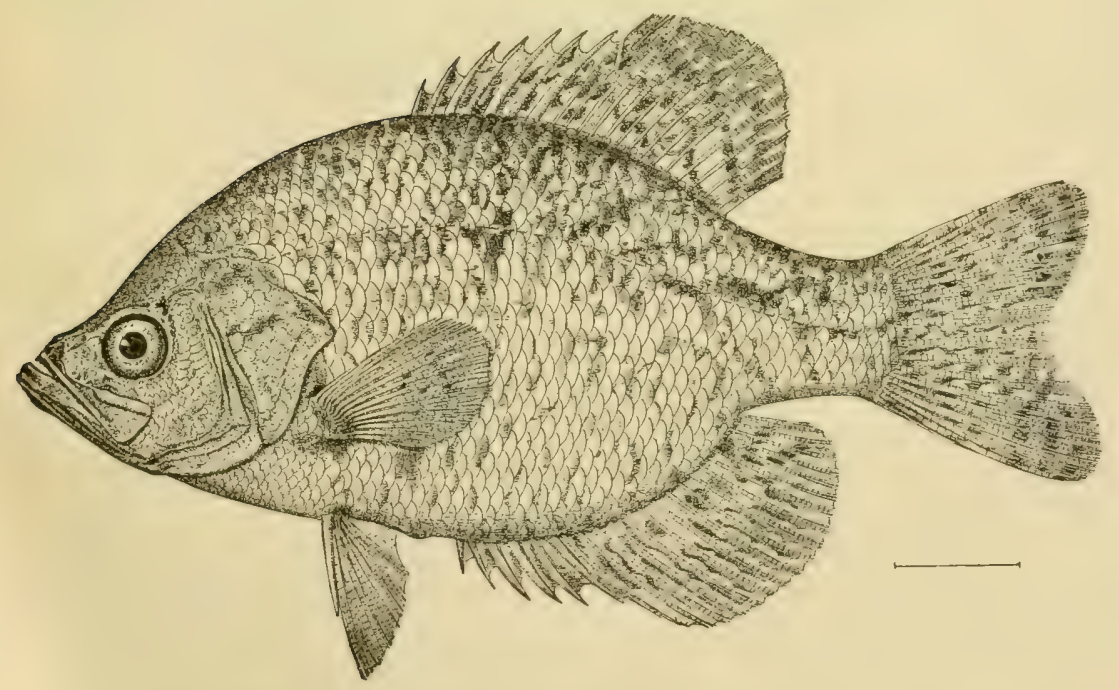

Ponoxis sparondes, Calico Bass, Strawberry Bass.

calico bass and crappie, anglers and fish-culturists frequently confound the two, the common and local names often being used interchangeably throughout the regions to which both are native.

P'ossibly no common name of the black bass is more appropriate than "jumper" which is applied in certain parts of Kentucky. It is difficult to capture them with a seine rigged in the ordinary manner, especially 
when they have the vitality and activity which is usual when living in water of moderate temperature, and in collecting brood stock it is well to use a seine about three times the depth of the water, as the bagging of a seine so rigged confuses the fish and deters them from jumping. While the black bass of the colder nor thern waters make a fight worthy of the salmon, they may be taken from the waters of the south with hardly a struggle.

liock bass are exceedingly pugnacious, and sometimes seem to take the hook rather on this account than from a desire for food. They are well adapted for pond-culture, and under proper conditions will repay the enlturist in a large crop of young with the expenditure of very little labor and time.

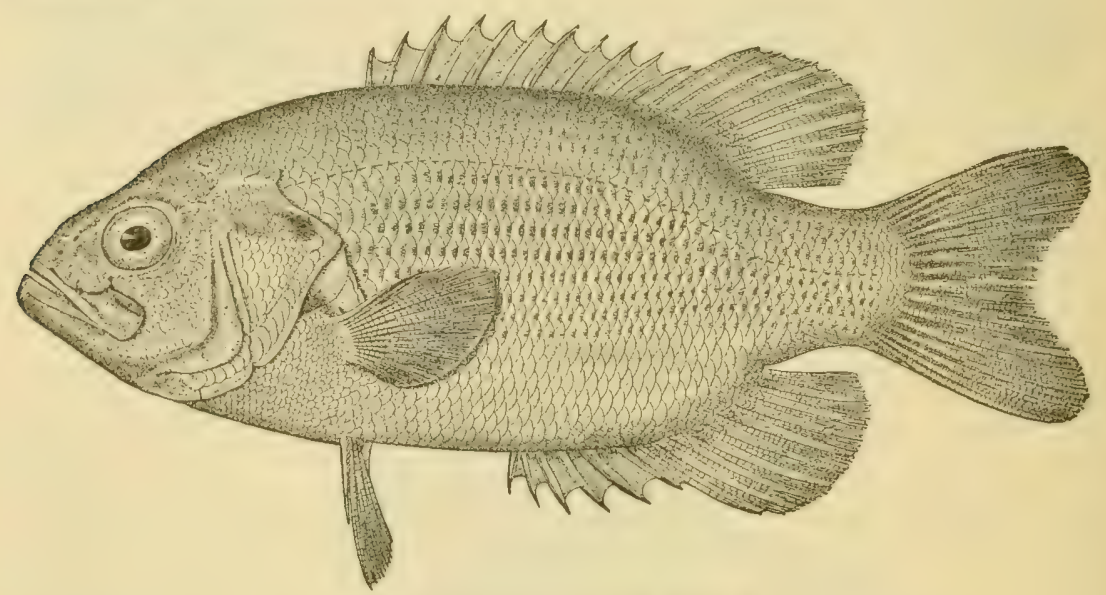

Amizloplites izUpestisis, liock Bass.

The calico bass is a fairly game fighter, and its firm, white flesh has a fine tharor when the fish is taken from cool, pure waters; but it is a very delicate fish to propragate artificially. It seems to resent captivity, and especially when taken from warm waters is exceedingly tender, quick to yield to attacks of fungus, and liable to become blind aud die. Of large numbers collected and transplanted in new waters many have died within a few days after being deposited.

The spawning and breeding habits of the calico bass and the crappio are so nearly like those of the rock bass that special remarks on the subject do not appear necessary.

\section{GROWTH AND WEIGHT.}

There is a wide difference in the rate of growth, and there is no way by which the age of a black bass can be determined from its size. Some are comparatively large from the moment they are hatehed, and grow much more rapidly than the smaller members of the same school. The average size of adults varies in different localities, and may vary from year to year in any particular locality. The variations depend upon initial vitality, upon the scarcity or abunckance of food, and upon 
the range and space given the fish. At the age of 5 or 6 months the young bass measure from to to 8 inches, according to Jocality and surrommlings, though a few individuals are apt to run larger. In 1892, at Noosho station, a black bass, which was positively known to be nuder 18 months old, weighed on the scales 1 . pound $9 \frac{1}{2}$ ounces.

The large-mouth bass have been known to weigh 23 pounds, and a 6.pound or s-ponnd hass in the sonthern tributaries of the Mississippi and in the inland lakes of Florida excites no surprise. The small-month bass does not grow so large, 22 pounds probably exceeding their average size, though they occasionally leach 5 or 6 pounds. The rock-bass fry grow slowly, those 6 months old seldom averaging 2 inches in length. The adult usually weighs fiom $\frac{1}{2}$ to $\frac{3}{4}$ pound, occasionally reaching 1 pound; and examples have been recorded as high as 3 pounds.

The erappie and the strawberry bass will, as a rule, not exceed 1 pound in weight, though in Missouri the former has been taken as high as :; pounds. With similar environments, at 6 months old the young of both these species are about the size of black-bass fry of the same acre, possibly a little smaller. Each school will have a few individuals much larger than the majority.

\section{NA'TURAL HABITAT AND DISTRIBUTION.}

The large-mouth and small-mouth black basses are widely distributed. The large-mouth is indigenous from the Great Lakes and the lied River of the North to Florida, Texas, and Mexico, and rest to the Dakotas, Nebraska, and Kinsas. The small-mouth bass ranged formerly from Lake Champlain to Manitoba, and southward on both sides of the Alleghenies to South Carolina and Arkansas. The adaptability of these fish to extremes of temperature and their great tenacity of life under seemingly adverse couditions have made their distribution comparatively easy, and they have been successfully introduced into nearly all the sections of the United States to which they were not native, and into England, France, Germany, and Finlaud. They have been planted in California, Washington, Utah, and other Western States by the U.S. Fish Commission. In three years they became so numerous in Utah that 30,000 pounds were caught and marketed from one lake.

Two notable early instances of the successful transplanting of black bass in a primitive way may be mentioned, the fish being transferred in the tender of a locomotive-once in 1853, when the Potomac was stocked, and again in 1875, when, wuder the direction of the Commissioner of Fisheries of Virginia, adult black bass were removerl from the linoanoke River across the divide to the New River, a tributary of the Kanawha. Up to 1875 the Kanawha contained no bass, and its edible fishes consisted almost entirely of cattish, but for the past ten or a dozen years thousands of bass have been taken from New River and its numerous tributaries, draining ten counties of Virginia and running through parts of North Caroliua and West Virginia. New River was also successfully stocked with rock bass by the Virginia Fish Commission, the fish being brought from Holston River, a tributary of the Tennessee in 
Washington County, Virginia, in June, 1876, and deposited in the smaller tributaries of New River, in Montgomery County, Virginia, whence they have colonized the entire New River basin.

Few fish thrive in water of such extremes of temperature as the largemouth black bass, and, to some extent, the small-mouth. The former are found in water covered with ire and in that standing at $100^{\circ} \mathrm{F}$; ; but with both species sudden ehanges of temperature are apt to prove fata?.

The small-mouth black bass seeks pure, rapicl, fairly clear streams, and lives at higher elevations and in elearer waters than the largemouth. In the northern part of its range it becomes torpid in winter, but in the warmer waters of the Sonth it is active throughout the year. The large-mouth black bass also likes pure, clear water, but often inhabits the hot and stagnant bayous and ponds of the South. It has been seen in great numbers under conditions of high temperature aud muddy water which would ordinarily be fatal to all forms of arquatic life except of a very low order. Many die in such eases, but numbers live for months and some possibly for years. Those from hot, stagnant waters, however, have a soft, flabby Hesh, and are apt to be infested with parasites; they spoil quickly and are not palatable. They do not voluntarily seek such unfavorable surroundings, their presence there being attributable to accident. The bass thus found in the Mississippi Valley have been left by spring freshets, and, failing to go out with the slowly receding waters, they reproduce in great numbers in the ponds and lakes temporarily formed in depressions of the land. The neighboring areas are usually either rich alluvial meadows or swampy forests, from which the receding water drains an infinite quantity of natural food for the sustenance of the fish retained in the temporary ponds.

The rock bass is indigenous to the Great Lakes region and Mississippi Valley, and there is evidence to show that it is native to certain streams on the east side of the Alleghanies. It has been successfully introdnced into many new waters. In its native waters it is found in the winter months under ice, yet it stands a high summer temperature, though not so great as the black bass. The highest temperature to which it has been subjected at Neosho is $88^{\circ}$. In transportation this species seems to suffer from change of temperature as quickly as the black bass, with possibly this difference, that while the black bass seems to be more quickly and fatally affected by a change from high to low temperature, the opposite change more quickly and injuriously affects the rock bass. 'Though sometimes found in muddy bayous and in waters stained by decaying vegetation, the rock bass thrives better in clear, pure waters well stocked with aquatic plants.

The natural habitat of the calico bass is the Great Lakes region, the entire Mississippi Yalley south to Lonisiana, and the streams of the Carolinas and Georgia east of the Alleghanies, while its close kin, the crappie, is confined to the Mississippi Valley, though sometimes taken in the Great Lakes region. The calico bass is said to need a higher temperature and clearer water than the crappie, but this is not certain. 


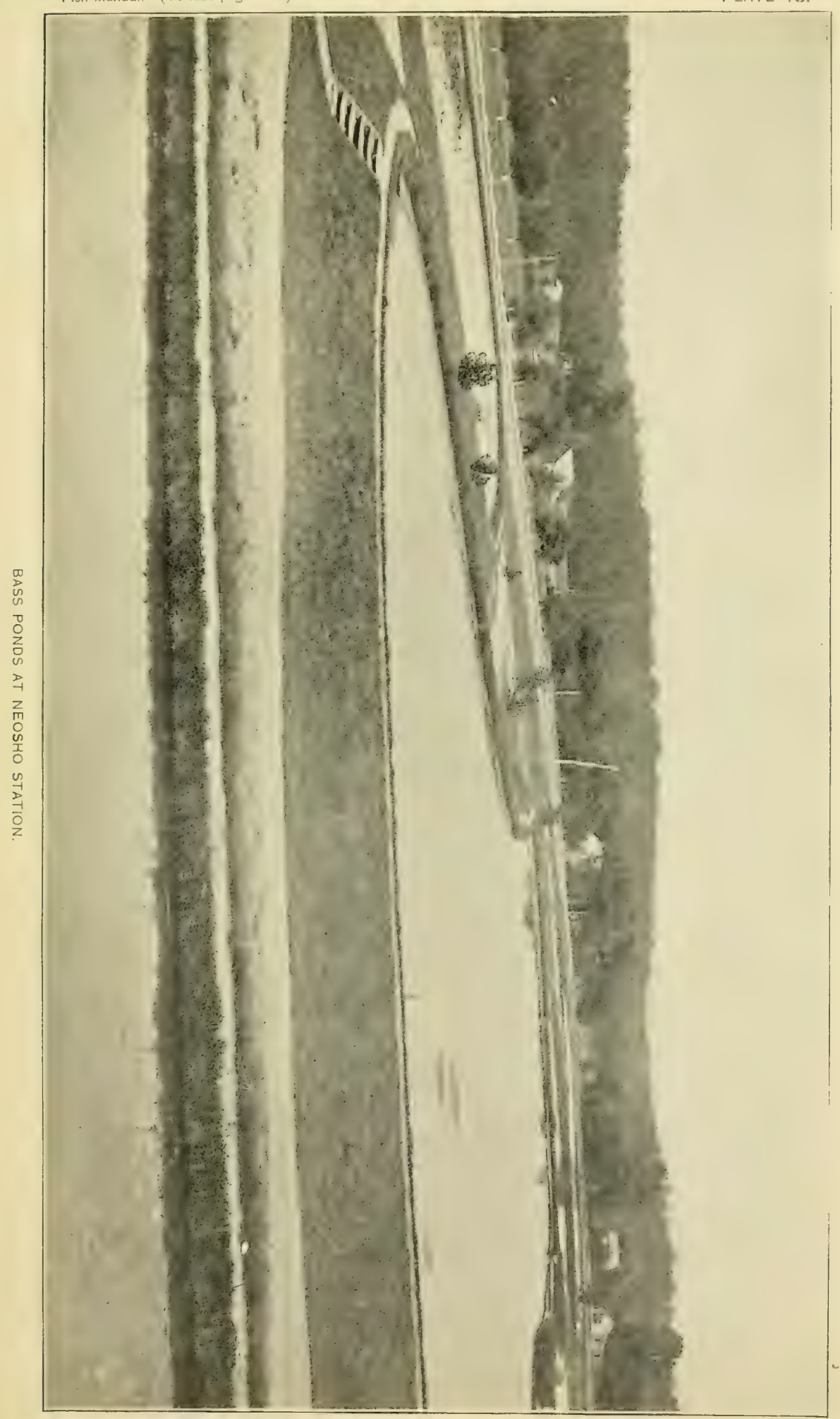



NA'TURAL FOOD, ETC.

The natural food of the black basses varies greatly and is influenced by the spawning season, character and temperature of the water, and the weather. The adults are voracious and pugnacions, and devour other fish almost indiscriminately; their food comprises cratfish, minnows, frogs, tadpoles, worms, and mussels, while the young feed on insects and other minute forms of life found in water.

At times both the large-mouth and the small-month bass refuse the most tempting bait, and at other times they bit greedily at almost everything. Various kinds of animals of a suitable size, even rats and suakes, and many varieties of vegetables, have been found in their stomachs, and in a wild state under some couditions they devour almost anything moving in or immediately over the surface of the water.

The black basses aftord perhaps the highest type among fishes of parental care and watchfulness, guarding their young until after the dispersal of the school of fry; but many of the young, so zealonsly protected early in the season, subsequently furnish food for adult bass, possibly their own progenitors. As with trout, bass of the same school of young vary in size, and the larger prey mercilessly on the weaker, often attacking their own kind, even when other natural food is abundant.

COMMERCIAL IMPOR'IANCE.

The market value to the fishermen of the black bass taken in the United States amounts to about $\$ 130,000$ annually, a sum representing over 2,000,000 ponnds of fish. A large part of the bass canght, however, never reaches the market, being consumed by anglers and their friends. The indirect value of bass fishing to rural districts, in the expenditures of visiting sportsmen for boats, guides, teams, supplies, and accommodations, is very great.

Ten years ago it was said that black bass did not exist in sufficiently large numbers to ever become a staple article of food, but they now furnish important additions to the food supply of many thousands of people. The annual sales in New York City are estimated to be at least 50,000 pounds, with an average value of 10 cents per pound. The States in which the black-bass tishery is most important are North Carolina and Ohio; in 1897, over 535,000 pounds, valued at $\$ 23,600$, were caught for market in North Carolina; in Ohio, nearly 300,000 pounds, worth over $\$ 22,000$, were taken. Other States, in which there is an annual yield of over 100,000 pounds, are Arkansas, Florilla, Minuesota, Missouri, and New York, and in about twenty other States this fish is of some commercial importance. The fishermen of Illinois ship nearly 50 tons of black bass to the markets annually.

The annual catch of crappie for market, according to recent statisties, is about 850,000 pounds, having a first value of $\$ 39,000$. The leading States in this fishery are Arkansas, Illinois, Minnesota, Missouri, and Tennessee, the three first named producing more than half the yearly yield. The market value of the rock bass is not large. Crappies are generally cousidered better food-fish than the rock bass and enter 
much more largely into commerce. As with black bass, a very large percentage of the catch of erappies, rock bass, and sunfishes does not reach the markets.

\section{LIMITATIONS OF BASS-CULTURE.}

Thlike the shar and salmon, the artificial propagation of black bass, by taking and impregnating the eggs, has not been, up to the present time. practically suceessful. The eggs can only be stripped with great difinenlty, and it has been necessary to kill the male to obtain the milt. Another obstacle is the difficulty of obtaining eggs and milt at the same time, even when the fish are taken from over the nests apparently in the aret of spawning. Interruption or handling seems to prevent the discharge of eggs or milt. At Nensho unsuccesstul efforts were made daily for several weeks to spawn a female black bass which was so near the print of spawning that when held head downward the eggs could be seen to roll forward toward the head, and when reversed to drop in the opposite direction.

Since a practicable way to artificially impregnate the eggs of the bass has not yet been developed, and the handling of eggs with indoor apparatus is impossible, it is fortunate that the natural impregnation of these fishes reaches a percentage closely approximating that which fish-culturists have been able to secure by artificial means from other species, and also that the parental instinct is unusually developed. The first conditions make pond-eulture necessary, and the second render it possible. The methods hereafter described are those in use at Neosho station.

\section{ARTIFICIAL PONDS.}

The size of spawning-ponds for rearing bass depends largely on the amount of land available, its topography, and the water supply. I'onds not less than $\frac{1}{2}$ acre in area, with the inlet at one end and the outlet at the other in the line of the longest axis, generally produce the best results, though smaller ponds have been suceessfully used.

It least one-fourth of the pond should be not over 1 foot in depth, and this portion should be planted with pond-weed (Potemogeton) and water-weel (Elodea or A nacharis) to facilitate the production and growth of the minute animals which funish so large a part of the food for the yomng bass. 'The rest of the pond should have a gradually sloping bottom and a conserquent increase of depth to the kettle (or draw-off), where the water must be at least from 5 to $($ feet deep for the warm Sonthern States, and is to 10 feet deep for the Northern States, to provide against the danger of freering. In the middle third of the pond water-lilies stionld be planted, preferably those with large pads, such as Nymphere alba; these plants not only furnish the breeding fish a hidingplace from fish-hawks, but serve as sunshades during the summer. It is not advisable to place large bowlders in the pond, as they are in the way of seining or netting and furnish an acceptable resort for crawfish. 
Nursery ponds should be constructed to aftord young bass protection from enemies and to produce the greatest quantity of insect life suited to their susteuance, and this is better accomplished with a number of small ponds than with one large one. A good working size is fiom 40 to 50 feet loug by 12 to 15 feet wide, with a depth of from 30 to 36 inches for the "kettle." Where the topography of the gromul will permit, it is best to have the nurseries immerliately adjoining the spanning-pond, with the water supply from the same source, so that there will be but slight diflerence between the temperature of the shallowest part of the nursery-pond and the surface water of the other.

The young large-mouth bass is not a strong fish, and currents in the spawning and nursery ponds should be avoided for some time after the spawning period.

If the locality is infested with craw fish, it is advisable to pile or otherwise protect the banks; and the entrance of snakes, frogs, and such enemies may be prevented by surrounding the pond with finely woren screens, or, better yet, boards let into the earth a few inches and projecting above the ground. The pond should be supplied with the aquatic plants previonsly mentioned as desirable tor the shallow parts of the spawning-pond.

A spawning and nursery pond may be combined by constructing one comparatively long pond, narrow near the middle, so that the general shape will be like a dumb-hell with a very short handle. Across the narrow part is to be stretched a sereen of one-fourth inch wire cloth, which will confine the spawners to the deeper end of the pond, while the fry, following their instinct of moving upstream, will find their way through the screen into the upper shallower end. This form of pond is advantageous where for any reason only a few ponds can be built.

In addition to the nursery ponds, tanks 6 feet wide and 10 to 12 feet long and 5 feet deep, made of cement and brick, or wood, shonld be provided for holding the fish preparatory to shipment during the fall, and are also very convenient for handling the fry when they are being transferred from the spawning to the nursery ponds prior to being assorted as to size. At Neosho, where the fry are removed from the spawning-ponds at a very early stage, they are held in troughs similar to those in general use for trout culture. A trough 14 feet long with 4 inches depth of water at $57^{\circ}$, changing 2 gallous per minute, will support from 3,000 to 5,000 very young fry, and twice or three times as many rock bass will live comfortably under like conditions. The same general care aurl cleaning usually given to troughs containing trout fry is necessary in cultivating bass. The trough should be swept down twice a day and occasionally washed inside with a cloth, and the water supply, conduits, and outlets frequently examined and kept clear and clean.

The young bass is able to stand any temperature to which the sun raises the water of the nursery; those hatched in water at $56 \circ \overline{\mathrm{F}}$. will thrive two months laler with the temperature at $86 \circ$. But bass grown in a very high temperature are exceedingly tender, and can not be 
handled and transported until the approach of fall and winter has gradnally reduced the temperature and thus hardened them; they are al:so more liable to attacks of parasites, both external and internal. While bass can live in water ranging from $33^{\circ}$ to $98^{\circ}$, more noderate limits are desirable. The Cyclops and some other of the natural forms of food for young bass reproduce best at a temperature between $68 \circ$ and $70^{\circ}$, and can not resist higher than $95^{\circ}$.

\section{CARE OF PONDS.}

It is desirable that the ponds should be "wintered" each year-that is, entirely drawn off' in the antumin, thus leaving the berls exposed to the combined action of sun, winds, and frost. This tends to kill ont the larvid of the larger aquatic insects (dragon flies, beetles, etc.), and to increase the following season's supply of small crustacea, which furnish an important element of food to the young bass. This purifying process can be assisted by the free use of quicklime dropperl into the crantish holes. There is no danger of the lime injuring the fish the following year, and the limewater purifies the pond bed, besides killing the craw fish and the like.

The aceumulated decayed matter ought to be occasionally removed, the frequency for this depeuding on the character of the water supply, the amount of silt it brings into the pond, the character of the soil, and on the thoroughness of the yearly removal of the surplus vegetation. Scraping large ponds and hauling the accumulated muck involve considerable labor and expense, possibly more than the yield of the pond warrants, and in some cases it is advisable, once in four or five years, to lay the pond bare for an entire year and cultivate it in peas or some other deep-rooted vegetable.

While abuudant poud vegetation is favorable to a large production of fry, it is sometimes so luxuriant that it settles down in a blanket-like mass and smothers many of the young fish. Under such circumstances it should be removed some time in advance of lowering the pond level, and during the process should be earefully picked over, as some of the fry will be found among it. Wading into the pond leaves the bottom tracked with deep footprints, which, as the water recedes, catch and retain many of the young fishes, most of which die in a short time. To avoid this a strong but lightly built flatboat is used, which can easily be moved from pond to pond, as needed. At each end of the boat is a ring, through which a stake is driven at the point in the pond to be worked. The vegetation is raked from the water in small lots, and mloaded on the banks with a pitchfork. It should be promptly removed from the bank, as it will rot very fast and its presence is objectionable. At the Texas station, where the vegetation is very luxuriant, it is hauled to the banks with a long rake 8 f'eet wide, operated by two men, and is then removed by means of long-handled forks. This methorl is simple and very economical, two men accomplishing more than tive or six by the other method. 


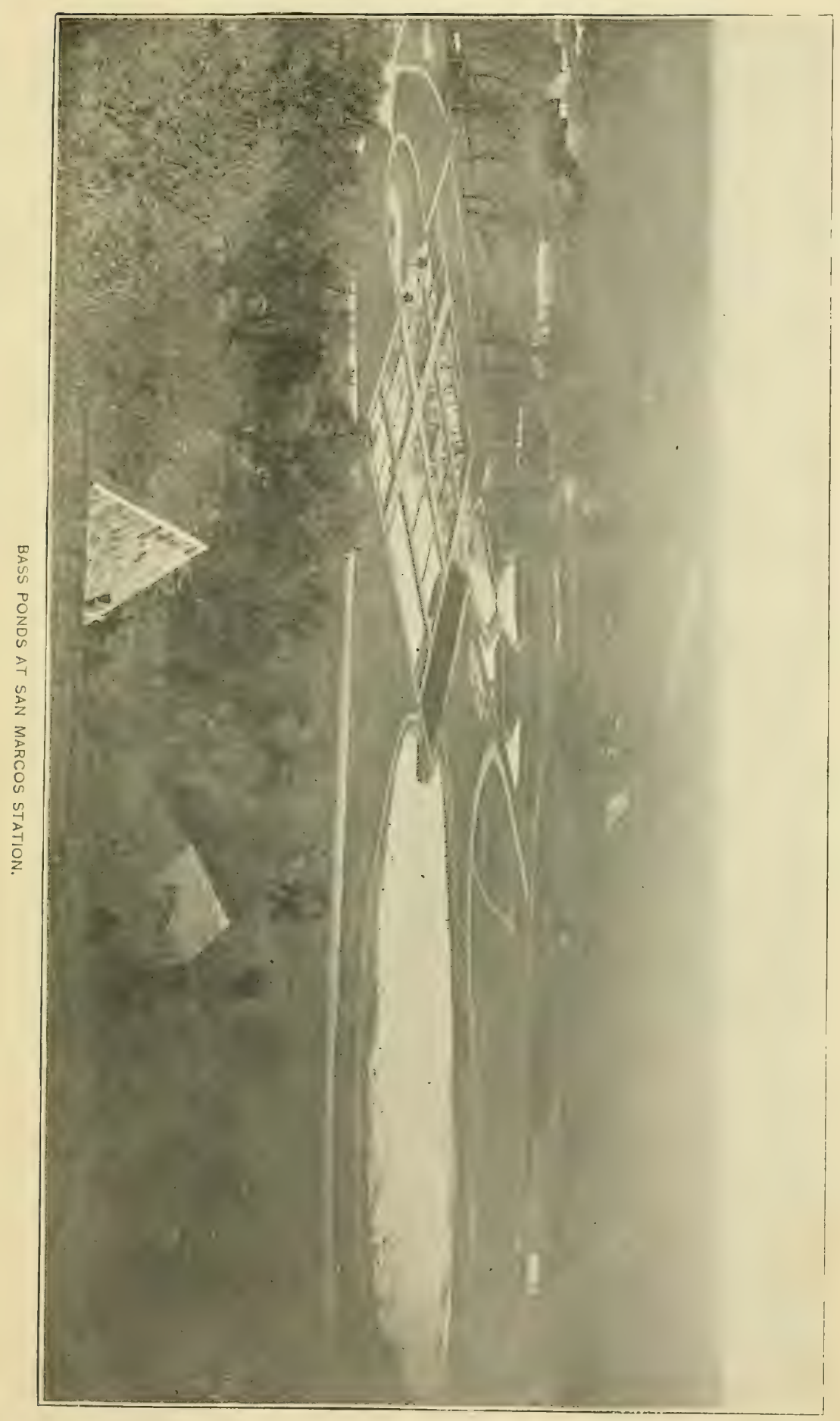





\section{NESTS AND NEST-BUILDING.}

Thenever the spawning period occurs, whether early or late, ample warning is given by the preparation of the nests, which are built by the mated fish, sometimes working in company and sometimes separately. In the Great Lakes region and the North and Niddle Itlantic States the nests are ordinarily built of gravel, brushed into neat cireular piles 1 s to :36 inches in diameter, and are usually found in water from 1 s to 36 inches deep, though not inferpently in much deeper water and sometimes in water less than a foot in depth.

In the proper preparation of the newly-built spawning-pond clean gravel, ranging in size from a buckshot to a hickory nut, is arranged in small hat heaps about 4 to 6 feet from the banks, as soon as the ice is ofl in the spring, in advance of the spawning season, and, if well lociterl, it can be used through several seasons and more than once in the simme season. Gravel probably possesses no arlvantage of itself over a hard-clay bed except that it presents more surface within a given area for the eggs to attach themselves to.

'The fish clean the gravel with the caudal fin and tail until it is as bright as if every particle had been polished with a brush, often using the head and mouth to remove the larger stones from the nest. Some bass build several nests in a season and are compelled to remove a comparatively large quantity of rough and jagged material, yet very few wounded or abrated bass are captured. At Neosho the same bass have been observed at nest-building for seven years without showing a torn or worn caudal or anal fin. Trout, on the contrary, wear their caudal fins and tails to the very bone, in their efforts, and often die in consequence. In the Mississippi Talley, in Texas, and throughout the Southern States, the black bass deposit their eggs on the clay or mul, and rarely use gravel. At the Texas station, where gravel nests were placed in the ponds they were seldom or never used.

The proximity of the nests to each other depeuds on the size of the pond and the number of fish. They are sometimes less than 5 feet apart, and in a spawning poud of the Michigan Fish Commission, having ouly 105 square feet of surface and containing 30 adult fish, there were $S$ nests. If the nests are near the banlis, in water from 18 to 3 ; inches deep, the entire process of spawuing and incubation is easily observed. The larger fish are apt to select deeper water, but they have been known to decline a clean lot of gravel, in water 3 feet (leep and $\mathrm{S}$ feet away from the embankment of the pond, to build a nest on the naked clay bottom within reach of the bank, on which people Tere passing almost every hour. Nesting bass should have sechusion, although those reared in captivity probably fail to notice minor disturbances at the time of spawning which would at other times alarm them.

Share is important, for, although bass sometimes build nests where there is no shade, in most instances they select places under overhanging grasses, lily-pads, stumps, and logs.

From the time the bass commence nest-building tho attendant heeps 
the pond and its contents under constant surveillance and maintains a close watch for fishhawks and herons. A record is kept, as nearly as practicable, of the date when each lot of eggs is laid, so that it may be known when to expect the young to hateh.

Artificial nests for bass have been used at one or two stations, as an experiment, but have heen abandoned except for rock bass at $\mathrm{V}_{y}$ theville, Va. The nest is a wooden box about 20 inches square, with sides 2 inches high and slightly flaring outward. Cleats are nailerl on the side for ennvenience in handling. Coarse gravel is placed in the bottom of the box and the remaining space is filled with fine gravel, flush with the top of the box. The top layer is sufficiently fine not to allow the eggis to fall through the spaces and mix with the large gravel underneath. The nest, thus completed, is placed in an excavation with the upher edge even with the bottom of the pond. A stake is driven near the nest and a board fastened to it, to afford sechusion aud protection from the sun and enemies.

\section{BROOD-FISH.}

Whenever procurable, domesticated tish are to be preferred to wild fisl for stocking the loreeding-ponds, as they are less liable to injury in handling and transportation. A disrupted scale, lacerated fin, or a bruise on head or body frequently canses the death of wild bass, and their native surroundings are such that it is difficult to collect any considerable number of then. Moreover, adult fish captured from their native waters frequently fail to spawn in the year or season in which captured, on account of fright.

lisass not over 'or or 21 pounds are recommended if the work is carried on in ponds which are to be frequently drawn off, but larger fish can be used advantageonsly if they are to be but rarely transferred to other ponds. Very large bass are more liable to injury when the ponds are drawn and the fish transferred, as they are more difficult to handle safely, and bruise and injure themselves in the tubs. Males and females should be in equal proportion, as an excess of males may prove a dis. turbing element at spawning time and later in the season may canse a loss by preying on the fry. The sexes of the black bass are not as easily distinguishable as of the trout. The number of adult fish for breeding-ponds depends non the food supply. For several years past at Neosho an average of 30 breeding bass to the acre of water has been allowed, but that number inight be increased.

\section{SPAWNING IABI'TS.}

When the rests are prepared and the smawning time arrives, the parent fish-especially the male-show considerable excitement and swim hark and forth over and around the nest. In the act of spawning they (rows the nest, their bellies close together, the male a little behind the female, and simultanemsly void the eggs and eject the milt, the real act of spawning oceupying a comparatively short time- 
a minute or less. The engs, when laid, are riseid, and as soon as voided and impregnated attach themselves to the floor of the. nest. Then commences a parental watchfulness worthy of imitation on the part of some higher aumals, one fish hovering immediately over the nest and maintaining a gentle motion of the fins for the purpose of lieeping the eggs free firm sediment, and the other acting as an outer sentinel, patrolling sor 10 feet away. Both male and female show great courage When whuling their eggs and young fry. I rock bass has been seen to leap entirely ont of the water to bite vicionsly at an attendant's hand when moving aside the grasses sheltering the nest, and a black bass when guariing its nest has been known to attack and kill a snake three times its own length. The brightness of the nest makes the parent on guarl easily distinguishable by enemies, like the fishhawk and eagle, but this danger may be materially lessened by planting the broatler-leaf water-lilies near the nests, to afford shelter when in danger.

Black bass begin to spawn in the northern part of the Enited States about the mirldle of May, while farther south the season commences as early as March, and in all localities it is later in deep than in shallow waters. In the far South, in waters uniformly warm, the spawning time may not depend entirely on the seasons. The period lasts about two months. Many, if not all, discharge only a part of their eggs at one spawning. The maturation of the entire oraries is never fully completed at one time, but the ripening is prolonged and the spawning done at intervals. As far north as southern Missouri and Illinois, black bass frequently spawn in the season following the spring when they are hatched, but this is not always the case; and farther north maturity comes later in life. Bass continue to yield eggs for a number of years, and some have been held in the brood ponds at Neosho which were adults when first taken to the station and continued productive for as much as seven years.

Rock bass have been kuown to produce two separate broods within one season as far north as southern Missouri, and this is probably true of some of the other basses. At Neosho they spawn when one year old.

EGǴS AND FRY.

The eggs differ greatly in number and size, according to the age and sizo of the fish, varying generally from 2,000 to 10,000 per fish and from 80,000 to 100,000 per quart; 17,000 aggs have been found in a largemonth liack bass weighing $2 \frac{1}{2}$ pouncis, a little less than $7,0 n 0$ to the pouncl of fish; but on another occasion a careful count of the mature eggs showed only 2,67t to the pound of fish. Wide discrepancies in the figures may sometimes result from different methorls of counting, as in rejecting or countiug small eggs which are commencing their maturation for the next production. The rock bass exg is fully three times as large as that of the black bass, and the fry are correspondingly large.

The varying factor of initial vitality and the impossibility of equalizing the intensity of sunlight render it impossible to determine pre- 
cisely the period of incubation of any eggs treated in pond culture. With some kinds, under extreme temperatures and other less understond fiuctors, wide variations are found. Bass eggs require from 7 days to : weeks for hatching, but usually from $\&$ to 10 days-depending mostly on the temperature of the water. Eggs artificially impregnated, in an experimental way, hatch in from 60 hours to 4 days at a temperature of $63 \circ \mathrm{F}$., or somewhat over.

Whem the fry leave the eggs, they remain on the nest till the sac is ahsorberl, this depending, as with other fishes, on the perior of incrahation. modified by the temperature or condition of the atmosphere; usually a fi fh less time being required to absorb the sac than for hatching the regris. When the sac is absorbed, the fry rise and form a school whieh hovers over the nest usually from 2 to 4 days, settling back at night, except in extremely warm weather, when they may scatter in a few hours. A sudden fall of temperature may canse the school to settle back and remain a day or two longer on the nest. The tactics of the parents change and they no longer stand guard orer the nest, but circle around the school, whipping baek truants and driving of intruders. When the school rises and hunger begins to be felt, the fry separate and are driven for protection, by the parent fish, into shoal water or into the thick grasses; there they are deserted. and dispersing they seek the minnte crustacea, larvir, and inserts. The brood bass should then be removerl from the spawning-ponds to other ponds, or confined in compartments in the same pond, so that they can uot prey on the fry.

For the first three to five days black-bass fry do not average onefourth inch in length and are almost colorless, until the pigment forms along the back, making them appear quite dark when viewed from ahove, though it is difficult to distinguish the color of an individual fish when caught on a net of bolting-cloth.

Very young rock bass seem occasionally to attach themselves to the sides and bottom of the nests and to submerged plants. This action has not been noticed with black bass, possibly because their nests, being in deeper water, are more difficult of observation.

\section{FOOD OF THE YOUNG.}

Just how much food to give bass fry is as difficult to determine as with any other young fish. They are very greedy, and, if arceptable food is given them, appear to he humgry nearly all the time, and it is more than urobable that the trombles canserl by overteeding other fishes would show themselves in the bass if they were overfed. If althy fry

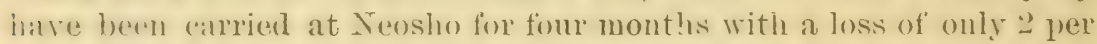
cent. When first brought into mursery ponds or troughs they can not he indued to take prepared food, as they are wild and must be tamed or domesticated. They are ferl aluost every hour in the day, though but little lood is given at one time and that is well seattered through the water. The attendant, without alarming them, should be about the trough constantly, to accustom them to his presence, and, instead of 
它

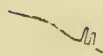

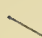

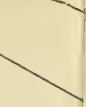

$\leftarrow$

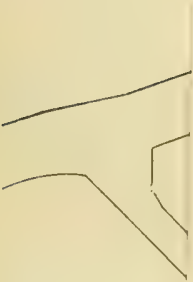

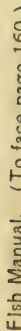



\begin{tabular}{l}
0 \\
$b$ \\
$w$ \\
5 \\
5 \\
\hline \\
0
\end{tabular}

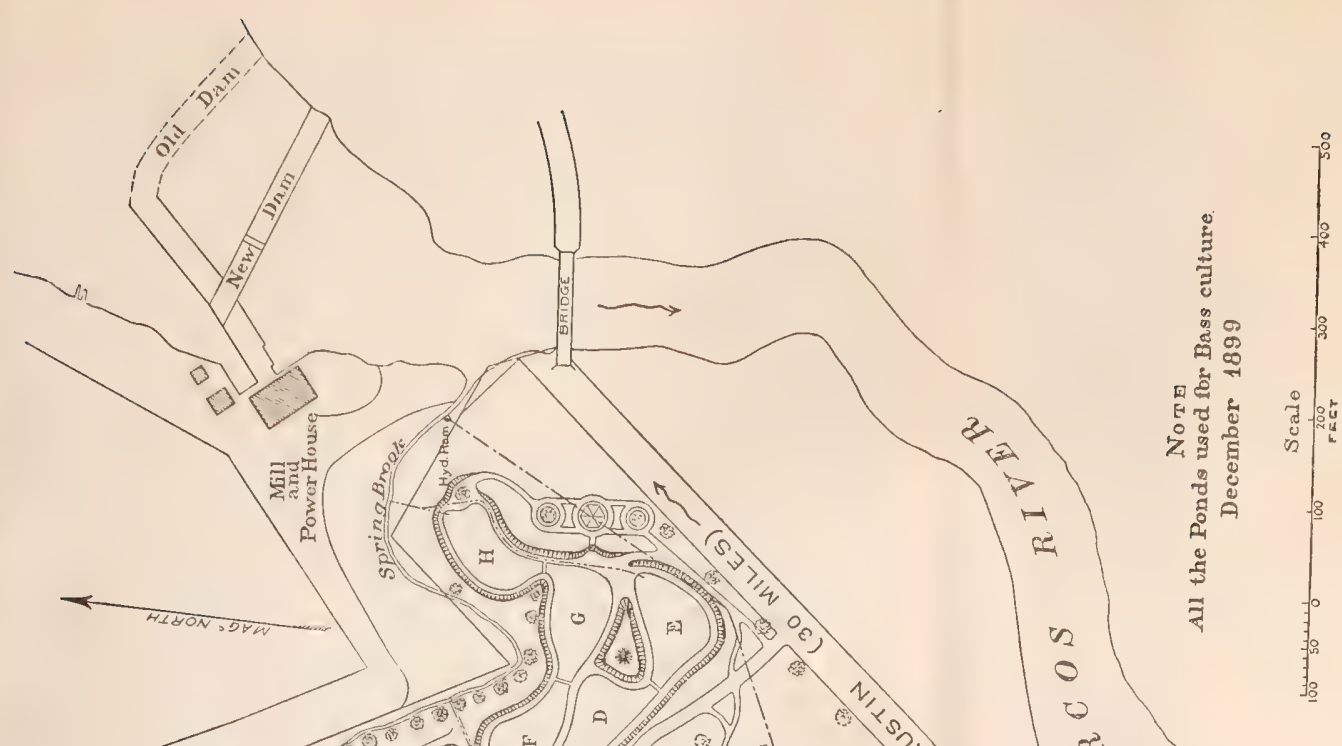

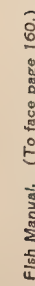
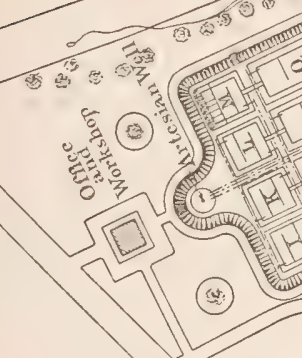

(4)
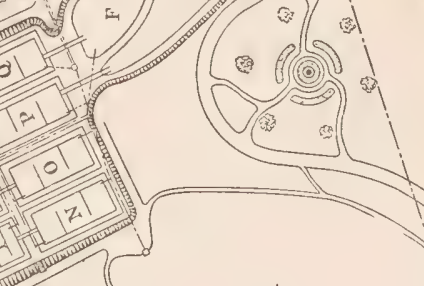

being frightened and darting into dark corners at his approach, they soon learn to come to meet him, not a few at a time, hut all together.

For several days their food will have to consist of such minute animals ats can be conveniently collected from the ponds with a dip-net of chessectoth. After four or five days they will accept prepared food, as fish of some lind, ground to a fine paste. In general, bass firy under Zt inches in length are ton small to talie artificial food, and it is very donbtful whether it is good policy to transfer them to nursery pouds or troughs prior to that stage.

The number of young bass to be put into a pond lepends upon its size and its capacity to produce food. If the nursery has been prepared in adrance with aptatic plants some crustacea will be found there, and the deficiency is supplied by the introduction of snails, Gammarus, Corixa, ete. The use of beef liver as food is not advised. To a nursery in far condition from 3,000 to 5,000 young bass may be allotted. The death of a pirt of these must be expected, and if even a fair percentage are to survive they must have much more food than the poud can probably grow. Should a large part of them survive the first few weeks they can be distributed into other nurseries.

At Neosho finely ground crawtish have heen used for food with good results-not that craw fish have any value orer other forms of aruatic life, but they are abundant, cost nothing, and are acceptable to the fish. Carp are cultivated for this purpose at the Fish Lakes in Washington, several hundred thousand being used each season, the young (an') being liberated in spawning-ponds with the young bass a few days after they are hatehed. At the Forest Ponds of the Missouri Fish Commission little branch chub are canght and placed in the pond several weelis before the bass spawn. As the chub spawn and hatch out before the bass, when the young bass are transferred to the nursery they find a lot of young chub ready to be eaten. An objection is that the old chub destroy the young bass, though this is easily obviated by batehing the chub artificially and turning only the young chub into the pond, or by removing the adult chub before the bass fry are introduced. At San Mares the bass fry are fed on young carp, buffalo, and mud shad, in addition to the natural food, which is quite aloundant early in the season, but later they take chopped fish, salted fish roe, etc. No effort is made to furnish the prepared food, though, until they reach $1 \frac{1}{2}$ inches in leugth, as they remain in the sparning ponds until that time.

\section{TRANSFER AND CARE OF FRY.}

In transferring the fry to troughs or other ponds at Neosho two nets of "heese-cloth are required. The main one is about 30 inches square, supported by ribs from above; to the center of the ribs a handle is attached, so that the net can be used 5 or 6 feet from the shore; the net is made to sag to an open pocket in the center, which can be closed and tied with a dlawstring. The second net is easily made from an 
ordinary landing-net by replacing the netting with cheese-cloth. This will be useful in catching the fry that escape from the larger net. The transfer is male in tubs filled with water from the spawning-pond in orler to preserve the same temperature as nearly as possible. Netting is dome in the early morning, as the shallow waters of the pond become cool during the night and the temperatures of the difierent waters are more nearly equal. It requires patience and a degree of skill, which comes with practice. The operator stands on the liank and introrluces the net with a gentle and scarcely pereptible side movement muler the school and cantionsly lifts it out, and when the net is clear of the vater, turus with a quick motion and brings it over the tub, so that the part of the net holding water and fish can be readily submerged in the tub. An assistant stands near the tub to catch the vides of the net anc lielp in the latter part of tho operation. While the operator holds the rod to which the frame of the net is attached, the assistant slips his hands into the tub and unties the drawstring of the net pocket, and the net is then gently lifted out of the tub. A bucket of water from the pond and a dipper are kept at hand to wash into the tub any of the fry that may stick to the cheese-cloth. The fry should never be freed from the net with a feather or by shaking.

As soon as the collected fyy are in the vessels they are carried to the troughs or pools, when the temperature of the water in the bucket or cans is compared with that flowing through the troughs. The experienced fish.eulturist cau tell by the touch whether there is a material difference in the temperature, aud can take the steps toward erpualizing it. Should there be a diflerence of $3^{\circ}$ or more, it must be corrected. If a vessel is not crowded, an effective, but slow, method is to set or suspend the vessel in the water flowing through the ponl or trough. If the water in the vessel is warm and the time short, in addition to setting the vessel in the trough, a part of the water may be bailed from the vessel and replaced with fresh colder water. This operation is called "tempering"; it requires care, good judgment, and patience.

It is well to have several large buckets made with "windows," that is, a small screen of perforated metal in one sicie of the bucket, near the top. This bucket is put in a trough unler a small jet of water, conducted by a rubber tube to the bottom of the bucket. The jet rischarging at the bottom of the bucket, and the surplus water escaping through the perforated window, assist in eyualizing the temperature, and the fish are then carefully put into the troughs or pools.

A part of the fry do not find their way through the wire sereens into the "ut-off, and all around the margin of the pond, even in the deep water, straggling fry may be seen. Sometimes these seattered youngsters are small, but generally they are the largest. After all the fry have been captured from the cut-off and the season's spawning is over, the pond is drawn to collect and save those that have failed to come into the cut.off. This work is generally in June or JuIy, when the 
ponds are quite warm and the temperature of the atmosphere is high, and is carried out with extreme watchfinhess and care, as the midsmmmer drawmg of a bass pond is the most delicate opresation connected with the propagation of this species in ponds. These fry ueed to be "tempered" and sorted in the same way as advised for other fiy.

At some stations of the Commission the fry are not transfereed from the spowning to the nursery ponds until they are $1 \frac{1}{2}$ inches long. In edfecting the transfer a seine made of wash-netting or bobinet is used, the length and depth of the net depending on the size of the ponds. The fishing is nsually done emly in the morning, near the inlet where the young fish collect. The fish are transferred from seines to tubs by dip-nets, and thence to the tanks, where they are "arefully assorted and placed in the nursery ponds. Sometimes they are assorted in the tubs and put at once in the ponds.

As the season advances it will be noticed that some of the fish grow much more rapidly than others, and as this is generally the result of cannibalism, the larger ones preying on the smaller, the fish must be again sorted and those of different ages placed in separate ponds. The successful raising of bass in pouds depends largely on frequent and eareful sorting.

Collecting for shipmentoceurs in the cool days of autumn, as experience has shown that the bass can be much better and more safely transported in the spring and fall than in the summer. They can be transported more cheaply in milwinter than any other time, but when fish are moved long distances in very cold weather (or at any other time when much ice is used in the cans) many die from gill troubles. After the ponds are free from vegetation and are ready for drawing off; the water level is reduced slowly. Every precaution is taken not to frighten the fish, and with this in view no more attendants are allowed abont the bank than are absolutely necessary. Black bass when frightened will burrow in the mud and live there an incredible length of time, and if a fingerling burrow in the mud when the pond is being drawn he may prove a dangerous oceupant the following spring when the young fry are introdnces. The same precautions should be observed in trausferring fingerlings as with the very young fry.

During the various stages of its life the bass is subject to the attack of enemies of many kinds. The fish-eating birds, like the kingfisher; wading birds, like the heron, and amphibions animals, like the mink and muskrat, must be guarded against. Snakes, frogs, turtles, and various beetles are dangerous to the firy, and sometimes even to adult fish. 



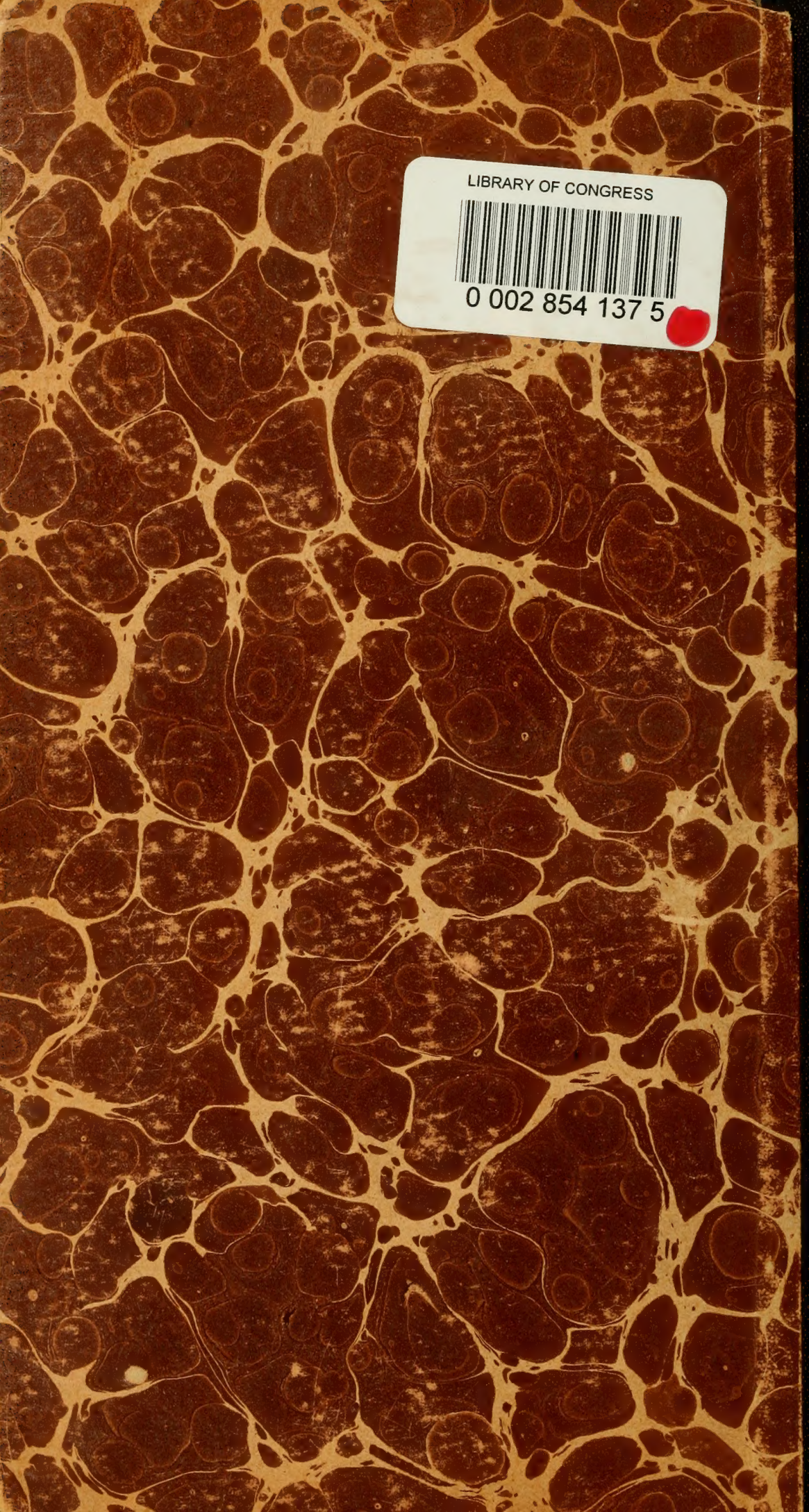

